\title{
The Impact of the Covid-19 Pandemic on Teaching and Learning Process: Review Research
}

\author{
Moh. Heru Budihantho ${ }^{1}$, Sari Listyorini ${ }^{2}$, Halim Dwi Putra ${ }^{3}$ \\ \{halim@polbeng.ac.id ${ }^{3}$ \} \\ STIA Bina Banua Banjarmasin, Indonesia ${ }^{1}$ \\ Universitas Diponegoro, Indonesia ${ }^{2}$ \\ Politeknik Negeri Bengkalis, Indonesia ${ }^{3}$
}

\begin{abstract}
The purpose of this study turned into to pick out acquiring data on the limitations of the teaching and learning technique on-line at home as a result of the presence of a COVID-19 pandemic. The have a look at used an exploratory case observe method and the studies approach used a qualitative case observe technique used to reap information on the restrictions and results of the COVID-19 pandemic towards teaching and learning activities in primary faculties. on this study, respondents have been 50 lecturers and 150 students in Malang-East Java. For confidentiality purposes, respondents are given initials. Semidependent interviews have been carried out and a list of questions compiled for interviews was developed primarily based at the associated literature. Respondents for this look at have been 50 teachers and 150 students in numerous campuses in Malang. The consequences of this study are that there are numerous limitations skilled via teachers and college students in on line teaching and learning activities, particularly mastery of technology remains missing, additional internet quota costs, there are additional jobs for lecturers and students in the teaching and learning procedure.
\end{abstract}

Keywords: Covid-19, Teaching, Learning, Process

\section{Introduction}

Currently there is an outbreak of the coronavirus. Coronavirus Diseases 2019 or often called Covid-19, which causes diseases ranging from mild to severe symptoms. There are at least two types of coronavirus that are known to cause illnesses that can cause severe symptoms. Covid-19 is a new type of disease that has never been previously identified in humans. Common signs and symptoms of Covid-19 infection include symptoms of acute respiratory problems such as fever, cough and shortness of breath. The average incubation period is 5-6 days with the longest incubation period of 14 days. On January 30, 2020, WHO has declared it a public health emergency that is troubling the world.

In August 2020, the city of Malang summarized the development of Covid-19 in the entire Malang Raya region based on infocovid19.jatimprov.go.id, positive patients of corona virus in Malang Raya totaled 1,377 patients. With the Covid-19 virus in Indonesia, it currently impacts the entire community. According to Kompas (28/03/2020), the impact of the Covid-19 virus occurred in various fields such as social, economic, tourism and education. Circular (SE) issued by the government on March 18, 2020 all indoor and outdoor activities in all sectors have been temporarily postponed to reduce the spread of corona, especially in the education sector. On March 24, 2020 the Minister of Education and Culture of the Republic of Indonesia issued 
Circular Number 4 of 2020 concerning Implementation of Education Policies in an Emergency for the Spread of Covid-19, in this Circular it was explained that the learning process is carried out at home through online/distance learning carried out to provide a learning experience meaningful to students. Studying at home can focus on life skills education, among others, regarding the Covid-19 pandemic.

Learning that is carried out in elementary schools also uses online/distance learning through parental guidance. According to Isman [1], online learning is the use of internet networks in the learning process. With online learning students have the freedom of time to study, can learn whenever and wherever. Students can interact with the teacher using several applications such as classroom, video conference, telephone or live chat, zoom or via the WhatsApp group. This learning is an educational innovation to answer the challenges of the availability of varied learning resources. The success of a model or learning media depends on the characteristics of the students. As expressed by Nakayama that all literature in e-learning indicates that not all students will be successful in online learning. This is due to the learning environment and the characteristics of students [2].

Every activity that is carried out must have pros and cons as well as the online learning system that is starting to be implemented in several cities at this time, including the city itself. However, there are still some lecturers and students who do not agree with this online learning [3]. According to Putra [4], regarding the Covid-19 outbreak which required peoples working from home or do online learning became more exhausting for more productive results. In fact, immunity became a decrease. Basically, the human body has an immune system to fight viruses and bacteria that cause disease. The purpose of this study was to obtain reason information from lecturers and students who disagreed with online learning.

\section{Methods}

This research is a social research which is included in non-experimental research using a scientific paradigm based on negative views or quantitative paradigms. This study describes a causal relationship with the Covid-19 phenomenon on online learning by lecturers and students and then general conclusions are drawn. The location of this research is all areas in the city of Malang because the city of Malang, one of which is the city of students, has an impact on the spread of Covid-19.

The unit of analysis in this study is an individual. This research is a sample research. The population used in this study were active lecturers and students who did not agree with online learning

This research is also carried out in analyzing general opinion and trying to find out certain issues and knowing the level and tendency of the percentage of opinions on reasons that lecturers and students do not agree with online learning.

\section{Result and Discussion}

This survey was conducted to see the online learning that has been running for more than four months. This is in line with the Minister of Education and Culture Circular 9 March 2020, which calls for learning activities for schools and campuses to be carried out from home. 
Based on 150 students related to the enactment of an online lecture system with:

1. $55 \%$ answered that they disagreed with online learning due to signal constraints which became an obstacle for students in accessing the lecture module.

2. $15 \%$ answered that there is no infrastructure available for the preparation of online learning systems, universities need to do a lot of preparation, such as revamping and revitalization, both in terms of infrastructure, infrastructure, but not all campuses can have good facilities so students don't necessarily have a gadget or devices that support online learning such as cell phones or laptops.

3. $10 \%$ think the cost of internet and applications is very expensive.

4. $8 \%$ think that some electronic devices require that they be connected to electricity, if there is a power failure, students will find it difficult to make attendance.

5. 5\% think they don't know how to go online through the application.

6. $3 \%$ thought that the fact was that what happened was not online lectures, but online assignments. Explained that there were lecturers who applied online lectures with very minimal material explanations, but always gave pile up assignments. This made him confused about the assignments given, because the lecturer only gave assignments without being accompanied by information and provisions regarding the assignment.

7. $.2 \%$ think that students are not flexible in learning because there is no 2-way communication between students and lecturers.

8. $2 \%$ think they do not know how to access and use online lecture applications. However, based on 50 lecturers related to the implementation of the online lecture system, there are:

1. $60 \%$ thought the signal constraints were the barrier for lecturers to access the lecture module.

2. $20 \%$ thought that they did not focus on working because attention was shared with family members in the surrounding homes.

3. $15 \%$ thought they did not know how to study online through the senior lecturer application.

4. 5\% think that some electronic devices require that they be connected to electricity, if there is a power failure, students find it difficult to make attendance.

\section{Conclusions and Suggestion}

After technology became more sophisticated, science was no longer limited to distance and time. These two things have become a relativity at this time. To gain knowledge, people no longer really need to come to class. Now, only armed with a laptop and an internet connection, anyone can attend online lectures, students are not required to come to campus regularly. No doubt, this system reopens the opportunities for higher education for those who are busy working. In fact, online college services have been adopted by many universities in Europe and America. Even so, the survey proves that there are still some lecturers and students who do not agree to hold online lectures for various reasons put forward.

\subsection{Suggestion}

Learning also our needs rest is also important. If you feel bored between studying, don't push yourself. Make a break for a moment to entertain yourself so you can always concentrate on the online learning process. Online lecture policies to anticipate the spread of the Corona 
virus outbreak are considered less effective in this poor city because there are still some lecturers and students who refuse online lectures and some campuses are not yet ready for it. online lectures.

\section{References}

[1] A. Isman and F. Dabaj, "Roles of the students and teachers in distance education," in Society for Information Technology \& Teacher Education International Conference, 2004, pp. 497-502.

[2] M. Nakayama, H. Yamamoto, and R. Santiago, "The Impact of Learner Characteristics on Learning Performance in Hybrid Courses among Japanese Students.," Electron. J. e-Learning, vol. 5, no. 3, pp. 195-206, 2007.

[3] A. Sobron, Bayu, Rani, and Meidawati, "Student Perceptions in the Study of the Effect of Online Learning on Science Learning Interest," SCAFFOLDING J. Islam. Educ. Multicult., 2019.

[4] H. D. Putra, "Do We Need To Be Productive During A Global Pandemic Covid 19?," Int. J. Psychosoc. Rehabil., vol. 24, no. 7, pp. 9555-9557, 2020. 